\title{
GOVERNMENT AND OPPOSITION - THE BINOMIAL DEMOCRATIC GOVERNANCE
}

\author{
A. G. Marinescu, C. Popescu
}

\author{
Alina Gabriela Marinescu \\ Faculty of Socio-Humanist Sciences \\ University of Piteşti, Piteşti, Romania \\ Correspondence: Alina Gabriela Marinescu, University of Piteşti, 71 Republicii Blvd, Piteşti, \\ 110014 \\ E-mail: alina.marinescu74@yahoo.com
}

\section{Cornel Popescu}

Faculty of Socio-Humanist Sciences

University of Piteşti, Piteşti, Romania

Correspondence: Cornel Popescu, University of Piteşti, 71 Republicii Blvd, Piteşti, 110014

E-mail: popescucorne185@yahoo.com

\begin{abstract}
:
An essential aspect of the political relations is represented by the relation between power and opposition, the power being in the meaning of this relationship the legitimate capacity to impose its own will or to exert the authority, which reveals a relation of domination. The two socio-political entities, government and opposition, acts by its specific means and in a democratic system these ease the confrontation of ideas, solutions, open competition between political forces generating the alternation in power, as a result of the electorate's will and political orientation.

Generally, the power is assimilated to the force or capacity of constraint, which suggests that, from a certain perspective, the imposition of the political will.

In the socio-political area, J.J. Rousseau in his "Social Contract" stated that the most powerful is not strong enough to always be the "master", if he does not transform the force into law and subjection into duty, so that the normative power shall emerge from a social morality stated by the law. As the pair term of the "power", the opposition is the ensemble of the political groups, parties or alliances, which, taken separately or as an ensemble, are opposing the political regime in force or the actual government's policy.
\end{abstract}

Keywords: democracy, government, power, opposition, authority

\section{Introduction}

The purpose of this research is the investigation of the content and socio-political dimensions of the relation power-opposition in order to establish a state of facts and to draft proposals on effective the interactions.

The conceptual analysis of the relation between power and opposition is made through its components, based on the complexity and diversity of the notions of "power" and "opposition". Are being analyzed both the methodological approaches focused on the study of the relations of power, as well as the main ideas in this area. A special attention is paid for the investigation of the specificity of the relations between the political power and opposition in the context of the democratic transformations, as well as in the context of the consolidated democracies.

Both the policy and the politics can be defined only by the relations configured for the achievement of their goals and purposes. The politics, according to D. Fisichella, can be built 
after the clarification of the "issue regarding the definition of the political relations". The political activity has always manifested only by relations "by which persons and groups exert the power or the authority in order to maintain the order in a territorial framework". During the evolution of the "zoon politikon" also changed the framework and entourage for the manifestation of the political relationships, their internal and external orientation, the leading actors, but the essence remained the same, the political relationships being relations for the organization of the society, for management and exertion of the governance, process that involves the political actors representing a dichotomy of the politics: political power and opposition.

The concept of political power is important and determinant for the identification of the specificity of the relation power-opposition. According to L. P. Zăpârtan "without any doubt, the concept of political power has a central position in every politic construction". The object of the research does not regard the general concept of power, but especially its relational feature, assuming besides the existence of the carrier of the power and the agent who is influenced by it. And he is not just influenced, but he opposes the influence and domination, the governing being achieved by the carrier of the political power. This is why in the present paper the effort of the author shall be focused on the theoretical reflection, and not on the content of the concept of "political power", but on its finality, on the teleological perspective. Essentially, the political activity is the activity to conquest, maintain, monitor, exert and communicate the political power. Most political specialists in their attempts to define policy have mentioned the important role played by the political power.

Starting with the studies of the ancient philosophers and ending with the theories of the contemporary political scientists, most authors have analyzed the political phenomenon in terms of the political power - Plato, Aristotle, Cicero, Thomas Aquinas, Machiavelli, Th. Hobbes, de Tocqueville, Montesquieu, M. Weber, R. Dahl etc.

The particular analysis of the concept of political power, from the perspective of the relation power-opposition, it is necessary because there are multiple methodological approaches of this subject, hence the diversity of meanings. By the way in which the concept of power is treated it definitely depend the conceptual content of the relation poweropposition.

For instance, if we analyze the political power only in relation to the state powers, then there is a risk to miss scientific issues such as the elections, public opinion and civil society's attitude etc. On the other hand, if we analyze the political power only from the light of its relational feature, then the concept of political opposition fits within the concept of power and yet again we are limited in our scientific exploration of the concept.

Studying the literature assumed the identification of four main principled scientific approaches of the political power, as a component of the political relation power-opposition: anthropological, sociological, legal-institutional, and behaviorist. The anthropological approach is synthetized by the studies of G. Balandier, P. Clastres, J. W. Lapierre. Therefore, G. Balandier starting from the anthropological approach of the phenomenon considers that: "resorting to the synthetic formula, the power shall be defined as emerging, for every society, from the need to fight against the entropy which threatens with disorder". The author draws attention on the organizational and integrant feature of the political power, which in different historical moments, by different forms of manifestation ensured the coagulated and organized feature of the human society.

An important role in the arsenal of instruments of the state has always been played by the coercion, which according to anthropologists is the element which determined the passage from kinship relations to political relations in the organization of society. The subject of using the force, the coercion, in the process of exerting the power is a subject as important as that of the relations of power. The coercion is not necessary only for the power, as well as for the whole society. P. Clastres moves further in correlating the terms power-opposition stating that the "power in in its essence coercion". 
Another author, the anthropologist M. Smith synthetizes the idea according to which the power is only "the capacity to effectively act on people, using a variety of means from persuasion to coercion". The awareness on the role of coercion derives from the teleological aspect of the power to ensure social order and organization. We must be totally aware of the fact that there is "no other society in which the rules are automatically accepted". Especially rules imposed in the virtue of the behavior code enlightened based on the opinion of majority. And where is majority, there is minority, which can disagree the provision of the prescriptive code imposed by the majority.

In this regard, there are not, at least at this moment, societies without contradictions and opposition, hence there are not homogenous societies and even the totalitarianism has pointed out the existence of the opposition.

In the area of interest of the anthropologists we do not find the political opposition in its feature as an alternative to power. The opposition for anthropologists has a social shade and it refers to the resistance of the social structures to modernization. From the institutional perspective, the political power is the ensemble of the institutions and mechanisms connected to the state's activity in the exercise of its constitutive attributes.

The legal approach treats the political power in an impersonal manner; it is not interested in actors, but in institutions. According to the legal opinion, the relation political power - political opposition is an institutional one, as regards the relations between institutions representing the power (usually executive ones) and those representing the opposition (the legislative, by its factions of opposition).

The sociological approach of the political power scientifically initiated and grounded by M. Weber, represents a special point of view different from the theoretical visions previously analyzed.

The specificity is ensured by the fact that the scientist is not focused on the analysis of the institutions or functions of the political power, but of its social component - the actors trained in the performance of the political power. The relation between political actors representing the political institutions and citizens as social support of their authority represents a particularity of Weber's scientific point of view.

Treating the subject of the political power from the sociological perspective involves, even imposes, the consideration of certain terms necessary for the comprehensive awareness of the object studied as: authority and legitimacy. These concepts represent the justification of the actions of the parties involved in the relations of power, for the carrier of the power, to act, for the object of the action of power, the justification of the action in relation to his indications. In a democratic regime the authority and legitimacy refer both to the carrier of the power as well as to the political opposition.

The power assumes hierarchy, authority, a certain dynamics of the action and social organization, according to some strategies recognized and accepted in the democratic system. In fact, over the time, political analysis prove that the power is a specific mean of expression of the human relationships, resulted in the fact that certain people can determine, more or less socially comprehensive, the behavior of other people. This continuous and complex phenomenon is owed to the particularity that the society is constantly adjusting, producing its own social and cultural effect, transforming the mechanisms of power.

In fact, the power has the feature of authority, exerted by influence, persuasion, generically signifying the power to persuade. The politics usually refers to the meaning of capacity of a person, structure or political institution to be respected and to inspire subordination, the authority simultaneously representing the power to issue mandatory provisions or to impose obedience in the virtue of a mandate.

Both parties have the mandate given by the electorate. Usually the difference refers to the quantitative aspect. The authority and legitimacy of those who have the political power is explained by the majority of the votes received from the electorate, in comparison with the political forces representing the opposition. Political authority, seen especially from the legal 
perspective, has an abstract and impersonal feature. In the same time "belonging either to institutions, or reflected by laws, rules or customs with which the individuals temporarily identify themselves, the political authority cannot be separated from its individual carriers". Therefore, from the perspective of the political sciences, the personalization of the power is a natural process.

It is understood that the political authority must be approached in the context of the analysis of the relations of political domination, and as pointed out especially by political sociologists, the historic forms of authority meet certain features. These have been analytically described by Petre Andrei under the influence of certain French and German thinkers, thus the authority acts as an objective power, being in the same time a conscious product of the value judgments, is normative under the relation of the human actions and behaviors, assumes hierarchy and organized dependence otherwise it shall reach the anarchy, and last but not least the authority must be legitimate and necessary.

The relation power-opposition has different forms; the democratic experience revealing that, placed on opposite positions, the political forces in opposition can play both functional and dysfunctional roles. From this perspective, approaching the issue of the representative governance, characterized by three essential instances of the participation to the political life, to represent, to debate and to decide, a series of authors emphasize the natural logic of the opposition. This fact is expressed by weakening the opponent in order to enlighten, by contrast, his own capacities and projects, in the permanent fight between the opposition and governors acting in time and space, playing a decisive role in imposing the perceptions or favorable or detrimental images for one or other of the parties.

In this context, it returns to a political analysis, in identifying the shades and anticipate the consequences of that certain positions, by identifying the opponents, namely those with a governmental vocation and the peripheral ones, namely the protesters. Hence, it must be considered that if the opposition is manifested in a legal framework, institutional or outside the established political system then, from different reasons, real or artificial, it refuses the rules of the political game, resorting to unconstitutional means.

Thus, there is a parliamentary opposition, party or group of parties acting in the Parliament, criticizing the governmental policies and voting without a rational reason against them, in the virtue of the custom "to be against". In the same time, there is an extraparliamentarian opposition, whose form of fight is represented by the challenging of the power by demonstrations, repeated strikes and unusual forms of holding the institutions or public squares for the creation of a state of political and economic instability. Usually those who practice these forms convict any attempt to restore the public order, classifying it as a "violation" of the democratic principle and limitation of the human rights. In its extreme form, this type of opposition is transformed into violent movements of attacking the public institutions, with the purpose of forcing the taking of power.

The rights and duties of the opposition are manifested in ways different from a regime to another, according to the socio-historical conditions, certain formal regulations such in the case of some states where a certain political statute is recognized for the opposition, who have the right to offer answer to the government's statements or to be consulted in certain major issues, especially related to foreign policy. A common example is that of Great Britain, whose opposition forms "the shadow cabinet".

Generalizing the theoretic-methodological information analyzed, regarding the nature of the political power, from the perspective of the relation power-opposition, some conclusions are emphasized. Thus, the analyzed methodologies can be grouped in two categories. The first group is formed by the scientific-anthropological and legal-rational approaches which have an "impersonal" perspective over the political power in the light of its functions and institutions. The second group is formed based on the sociological and behaviorist approaches aiming more the "social" and personalized feature of the political power. 
Analyzing these two structured views, D. Fisichella considered that we can talk about a double valence of the notion of power. The political scientist considers that there is a relational and an institutional concept of the political power. Under the first aspect, according to the approaches initiated by R. Dahl, the power assumes such relation between social units (individual subjects and groups) in which the behavior of agent $\mathrm{B}$ depends on the behavior of agent $\mathrm{A}$.

This observation refers both to the exercise of power, as well as to its possession, regarding the institutional concept, when it refers to the political power as an institution, or using D. Fisichella's expression "a power holding and exerting the power".

\section{Conclusions}

The analysis of the political power from the view of the relation power-opposition is made from the perspective of both approaches of the concept of political power. Using D. Fisichella's feature by political power is shall be considered, with priority, the power holding the political power, and the opposition shall be the one who wants to gain this power for itself.

The power, from the institutional perspective, is the goal and finality of the competition between the governing political forces holding this power and the political forces who want to conquer it, being in opposition.

Placed on opposite positions, the power and opposition have different roles, in the meaning that the democratic experience shows that opposite political forces can play either functional and constructive or dysfunctional roles, by this becoming good or bad for themselves or the society.

\section{Bibliography}

M. Weber, Etica protestantă şi spiritul capitalismului, Humanitas Publishing House, Bucharest, 2003;

C. Pîrvulescu, Politici şi instituţii politice, Trei Publishing House, Bucharest, 2002; Iasi, 2000;

R. A. Dahl, Poliarhiile. Participare şi opoziţie, European Institute Publishing House,

D. Fisichella, Ştiinţa politică. Probleme, concepte, teorii, CEP-USM Publishing House, Chisinau, 2000; 2000;

I. Mitran, Politologie, România de Mâine Foudation Publishing House, Bucharest,

N. Bobbio, Dreapta şi stânga, Humanitas Publishing House, Bucharest, 1999;

S. P. Hantington, Ordinea politică a societăţilor în schimbare, Polirom Publishing House, Iasi, 1999;

G. Balandier, Antropologie politică, Amarcord Publishing House, Timişoara, 1998;

M. G. Smith, The study of social structure, Research Institute for the Study of the Man, New York, 1998;

G. A. Almond, S. Verba, Culturăcivică. Atitudinipoliticeşidemocraţieîncincinaţiuni, CEU- Press, Du StylePublishing House, Bucharest, 1996;

P. Braud, Grădina deliciilor democraţiei, Globus Publishing House, Bucharest, 1995; Iasi, 1992;

L. P. Zăpartan, Repere în ştiinţa politicii, "Chemarea" Foundation Publishing House,

P. Andrei, Opere sociologice, $2^{\text {nd }}$ Volume, Academy Publishing House, Bucharest, 1974;

P.Clastres, Echange et pouvoir: philosophie de la chefferie indienne, L'HommeReview, Paris, 1962. 